\title{
Effects of oxygen supplementation during the last stage of incubation on broiler performance, ascites susceptibility and some physiological traits
}

\author{
Umran SAHAN $^{\mathrm{a} *}$, Aydın IPEK ${ }^{\mathrm{a}}$, Ozge ALTAN $^{\mathrm{b}}$, Bilgehan \\ YILMAZ-DIKMEN $^{\mathrm{a}}$
}

${ }^{a}$ Dept. of Animal Science, Faculty of Agriculture, University of Uludag, Gorukle, 16059-Bursa, Turkey
b Dept. of Animal Science, Faculty of Agriculture, University of Ege, Bornova, Izmir, Turkey

(Received 9 May 2005 - Accepted 15 December 2005)

\begin{abstract}
The present study was conducted to determine the possible use of supplemental oxygen treatment during the last 3 days of incubation on broiler performance, ascites susceptibility and some physiological traits. On the 18th day of incubation, fertile eggs were divided into two groups. From 18 to $21 \mathrm{~d}$, the eggs were placed in two hatcher cabinets: one being a control at normal atmospheric conditions, $20.9 \pm 0.5 \%$ at $754 \pm 2 \mathrm{~mm} \mathrm{Hg}$ and the other supplemented with oxygen at $23.0 \pm 0.5 \%$. Oxygen supplementation had a significant effect on initial chick weight. At 6 weeks of age, body weight, growth rate, and feed consumption increased as partial pressure of $\mathrm{O}_{2}$ rose from 20.9 to $23.0 \%$. Feed conversion ratio decreased with the increasing partial pressure of oxygen. In the present study, general mortality and mortality due to ascites did not differ between the groups. At 5 weeks of age, oxygen supplementation did not cause significant changes in RBC (red blood cell count), $\mathrm{Hb}$ (hemoglobin) and Glucose. However, PCV (hematocrit) increased significantly as the partial pressure $\mathrm{O}_{2}$ rose from 20.9 to $23.0 \%$. There were no differences in the right ventricle, left ventricle + septum, total ventricle and RV:TV (right ventricle:total ventricle) ratio between the oxygen supplemented and control group.
\end{abstract}

oxygen supplementation / ascites / ascites heart ratio / physiological traits / broiler

Résumé - Effets d'un apport supplémentaire d'oxygène durant le dernier stade d'incubation sur les performances du poulet de chair, la formation d'ascite et quelques caractères physiologiques. La présente étude a été conduite pour évaluer l'utilisation possible d'un apport supplémentaire d'oxygène pendant les trois derniers jours d'incubation sur les performances du poulet de chair, l'apparition d'ascite et quelques paramètres physiologiques. Au $18^{\mathrm{e}}$ jour d'incubation, les œufs fertiles ont été divisés en deux groupes. De 18 à 21 jours, les œufs ont été placés dans deux éclosoirs, l'un (groupe témoin) sous conditions atmosphériques normales $\left(20,9 \pm 0,5 \% \mathrm{O}_{2}\right.$ à $\left.754 \pm 2 \mathrm{mmHg}\right)$ et l'autre (groupe expérimental) sous atmosphère enrichie en oxygène à $23,0 \pm 0,5 \%$. L'apport d'oxygène a eu un effet significatif sur le poids initial des poussins. A six semaines d'âge, le poids corporel, la vitesse de croissance et la consommation d'aliments ont été accrus avec la pression partielle en oxygène la plus élevée, alors que l'indice de consommation a été diminué. La

\footnotetext{
* Corresponding author: umran@uludag.edu.tr
} 
mortalité en général et la mortalité due à l'ascite en particulier n'ont pas différé entre les groupes. A cinq semaines d'âge, l'apport d'oxygène n'a provoqué aucun changement significatif pour la numération des globules rouges, le taux d'hémoglobine et de glucose. Toutefois, l'hématocrite a été sensiblement augmenté lorsque la pression partielle d' $\mathrm{O}_{2}$ est passée de 20,9 à $23,0 \%$. Aucune différence significative n'a été observée entre les deux groupes pour le poids du ventricule droit, le poids du ventricule gauche + septum interventriculaire, le poids ventriculaire total et le rapport du poids du ventricule droit au poids ventriculaire total (VD/VT).

apport d'oxygène / ascite / ascite d'origine cardiaque / paramètres physiologiques / poulet de chair

\section{INTRODUCTION}

Modern broilers have been intensively selected over many years for rapid attainment of maximal body mass and optimal feed conversion and this has resulted in anatomical and physiological limitation of blood flow through their lungs, with deficient oxygenation of their tissues as a consequence [15]. This has resulted in a marked increase in ascites, a syndrome that causes serious losses in broilers in many countries [28,35].

Oxygen requirement is the most critical trigger of ascites in broilers [16]. High metabolic demands together with decreased availability of oxygen, may lead to hypoxemia and ascites [15, 23, 27, 37]. Ascites susceptibility is particularly pronounced during the period of rapid juvenile growth when the metabolic rate is very high [7].

Although the peak incidence of ascites occurs in the 5th or 6th week of the growing period, the aetiology of the disease may be initiated much earlier, even during the embryonic stage [6].

Embryonic growth can be estimated by egg weight and $\mathrm{O}_{2}$ consumption at certain stages of development [10]. Rapid growth increases the oxygen requirement, cardiac output, and blood flow and may result in increased pulmonary arterial pressure primarily by increasing the metabolic demand for oxygen $[14,16,36]$. Chicken embryos grow rapidly over the last $7 \mathrm{~d}$ of incubation [18] resulting in a $60 \%$ increase in the oxygen consumption during the interval between the start of breathing and hatching [34]. Therefore, hypoxia, known to be involved in the occurrence of the ascites syndrome, could arise in the chick embryo during the interval between internal pipping and hatching [8]. In fact, Dewill et al. [8] reported hypoxic conditions in the late embryonic phase. Altan et al. [2] suggest that oxygen supplementation from 18 to $21 \mathrm{~d}$ of incubation could be used as an effective means of improving hatchability of broiler eggs. Oxygen supplementation during incubation could also increase embryonic growth rate and day old chick weight.

During the development of ascites syndrome, birds exhibit classic haematological changes. For example, hematocrit, haemoglobin and red blood cell count (RBC) all increase dramatically [21, 39]. Hernandez [9] reported that haemoglobin and HTC were $40 \%$ higher in ascetic broilers than nonascetic broilers housed at $2630 \mathrm{~m}$ above sea level. The lack of oxygen stimulates red blood cell proliferation to the vascular system causing an increase in hematocrit [29]. An increase in hematocrit results in higher blood viscosity and leads to pulmonary hypertension, right ventricular hypertrophy, oedema and ascites [15, 37]. Right ventricular failure and ascites are responses to the increased workload by the right ventricle as a result of pulmonary hypertrophy. Hypertrophy of the right ventricular wall and the ratio of the right ventricle to the total ventricle mass is directly related to pulmonary hypertension [15]. Right ventricle to total ventricle (RV:TV) ratio, haemoglobin, 
hematocrit and specific clinical chemistries can be used to determine the ascites status of a bird before gross lesions are apparent [11].

The aim of the current study was to determine the effect of using supplemental oxygen treatment during the last 3 days of incubation on broiler performance, ascites susceptibility and some physiological traits.

\section{MATERIALS AND METHODS}

A total of 720 eggs were obtained on the same day from a commercial broiler breeder flock (Ross 308) at 40 weeks of age. The eggs were sanitised and stored at $18{ }^{\circ} \mathrm{C}$ and $75 \% \mathrm{RH}$ for 5 days. The eggs were incubated in an incubator (Cimuka A1, Ankara, Turkey) at $37.2{ }^{\circ} \mathrm{C}$ and $54 \%$ $\mathrm{RH}$ for 18 days. On the 18th day of incubation, all eggs were candled and 650 fertile eggs were randomly divided into two groups. The first group was placed in a hatcher cabinet (Cimuka A2, Ankara, Turkey) at normal atmospheric condition. The percentage of oxygen was measured to be $20.9 \pm 0.5 \%$ at $754 \pm 2 \mathrm{~mm} \mathrm{Hg}$. The second group was placed in a hatcher cabinet (Cimuka A2, Ankara, Turkey) that was supplemented with oxygen from 18 to $21 \mathrm{~d}$ of incubation. The partial pressure of oxygen within this cabinet was regulated to $23.0 \pm 0.5 \% \mathrm{O}_{2}$ with a flow rate of approximately $5 \mathrm{~L}$ per min. The percentage oxygen was monitored daily with the use of an oxygen analyser (Drager Multi Warn II, Lade Modul). Both cabinets were maintained at $36.5^{\circ} \mathrm{C}$ and $72 \%$ RH. Digital thermometers were used in each hatcher cabinet to verify set point temperatures.

After hatching, 270 chicks per treatment (normal atmospheric condition and supplemental $\mathrm{O}_{2}$ at hatching) were reared. The chicks were weighed individually on an electronic balance with $0.01 \mathrm{~g}$ before being wing-banded and placed in environmentally controlled pens. The chicks were ran- domly distributed into 12 pens (six replicates of 45 chicks per pen, for each group). The chicks were reared on fresh wood shavings at a depth of 8-10 cm.

The chicks were brooded at 32.5, 29 and $27{ }^{\circ} \mathrm{C}$ during weeks 1,2 , and 3 respectively. From the 3rd week, all broilers were reared at a constant temperature of $21^{\circ} \mathrm{C}$. The chicks received a standard pelleted broiler starter diet $(22.0 \% \mathrm{CP}$ and $\mathrm{ME} 12.8 \mathrm{MJ} \cdot \mathrm{kg}^{-1}$ ) between the $1 \mathrm{st}$ and 14th day. A grower diet $(22.0 \% \mathrm{CP}$ and 13.3 MJ. $\mathrm{kg}^{-1}$ ) was fed between the $15 \mathrm{th}$ and 28th day. A finisher diet $(21.0 \% \mathrm{CP}$ and ME $13.5 \mathrm{MJ} \cdot \mathrm{kg}^{-1}$ ) was administered between the 29th and 42nd day. Feed and water were provided ad libitum. The lighting schedule was $24 \mathrm{~h}$ of light from days 1 to 5 and $23 \mathrm{~h}$ light per $1 \mathrm{~h}$ dark thereafter.

Individual body weights were recorded at 1, 3, 5, 6 weeks of age. Live weight gains and feed conversion ratios were calculated. Mortality and mortality due to ascites values in each pen were recorded daily. The mortality rates in the groups were determined depending on these data. All dead birds were examined for the presence of typical ascites lesions, as determined in previous publications [14,15,21], and mortalities due to ascites were recorded.

On the 5 week of the experiment, 10 chickens randomly chosen from each group were killed by deception and the hearts were removed and dissected to obtain heart weights in order to calculate the RV:TV ratio. This ratio was used as an index of pulmonary hypertension [11].

Approximately $1 \mathrm{~mL}$ of blood was collected for glucose concentration and hematological tests, which included red blood cell (RBC), packed cell volume (PCV) and haemoglobin $(\mathrm{Hb})$. Red blood cell count (RBC), packed cell volume (PCV) and haemoglobin $(\mathrm{Hb})$ concentration were determined using standard methods described by Schalm et al. [26]. Blood glucose was determined by the Glucose oxidase method (Sigma Chemical Co). 
Table II. Mortality due to other reasons and mortality due to ascites of the oxygen supplemented and control groups.

\begin{tabular}{|c|c|c|c|c|}
\hline \multirow[t]{5}{*}{ Treatments } & \multicolumn{4}{|c|}{ Dispersion of Total Mortality } \\
\hline & \multicolumn{3}{|c|}{ Other than Ascites (\%) } & \multirow{3}{*}{$\begin{array}{c}\text { Due to Ascites (\%) } \\
\mathrm{n}=9 \\
22-42 \mathrm{~d}\end{array}$} \\
\hline & & $\mathrm{n}=10$ & & \\
\hline & $1-21 \mathrm{~d}$ & $22-42 \mathrm{~d}$ & $1-42 \mathrm{~d}$ & \\
\hline & NS & NS & NS & NS \\
\hline Control & $1.484 / 270$ & $0.742 / 270$ & $2.226 / 270$ & $2.968 / 270$ \\
\hline $\mathrm{O}_{2}$ Supplemented & $0.742 / 270$ & $0.742 / 270$ & $1.484 / 270$ & $0.371 / 270$ \\
\hline
\end{tabular}

NS: not significant.

The research was carried out using a randomised-plots experimental design. The SAS [25] package programme was used in the evaluation of statistical analysis. Differences between means were compared using the Duncan multiple range test and Chi-Square analysis was used in analysis of mortality ratios.

\section{RESULTS}

Oxygen supplementation caused a significant increase in initial chick weight $(P<0.01)$. The effects of oxygen supplementation on body weight (BW), growth rate and feed consumption were found to be significant at 6 weeks of age $(P<0.05$; $P<0.01)$. BW and growth rate during the $1 \mathrm{st}, 3 \mathrm{rd}$, 5th and 6th weeks increased with increasing partial pressure of $\mathrm{O}_{2}$. At the 6th week of age, feed consumption and feed conversion ratio values of the oxygen supplemented group were significantly lower than the control group values $(P<0.01)$ (Tab. I).

The effects of oxygen supplementation on mortality other than ascites and mortality due to ascites are given in Table II.

Although oxygen supplementation did not have a significant effect on mortality, it is interesting to note that there was a difference of $2.59 \%$ in mortalities due to ascites between the two treatment groups. However, the reader should be aware that, numerically, this was a difference of only seven birds.
As shown in Table III, oxygen supplementation did not cause significant changes in $\mathrm{RBC}, \mathrm{Hb}$ and Glucose at 5 weeks of age. However, the oxygen supplemented group exhibited higher haematocric values than the control.

At 5 weeks of age, there were no difference in right ventricle weight and the RV:TV ratio between the two groups (Tab. IV).

\section{DISCUSSION}

Differences in growth and energy metabolism by the chicks subjected to the different treatments may have already occurred during embryonic development [1, $17,24]$. In the present study, oxygen supplementation in the hatcher cabinet resulted in a heavier mean chick weight. This observation was in agreement with that of Christensen et al. [5] who observed that at EP 23, oxygen in a plateau state increased BW when compared with the other treatments. The results of the current study are also in agreement with those of Stock and Metcalfe [30], who stated that oxygen limits the growth of the chick embryo. Indeed, previous studies have shown that supplemental oxygen in the incubator increases the availability of oxygen, which increases the rate of conversion of egg contents into embryonic tissues [31].

Growth, particularly which of lean tissue, increases the need for $\mathrm{O}_{2}$ consumption [4]. Maxwell et al. [22] and Witzel 
Table III. Mean haematological values and blood glucose concentrations of oxygen supplemented and control groups at the 5th week ( $\bar{X} \pm$ standard error of the mean).

\begin{tabular}{lccc}
\hline Blood Parameters & $\begin{array}{c}\text { Control } \\
\mathrm{n}=10\end{array}$ & $\begin{array}{c}\text { Oxygen Supplemented } \\
\mathrm{n}=10\end{array}$ & Significance \\
\hline Glucose $\left(\mathrm{mg} \cdot \mathrm{dL}^{-1}\right)$ & $274.00 \pm 3.54$ & $280.90 \pm 3.54$ & $\mathrm{NS}$ \\
PCV $(\%)$ & $32.89 \pm 1.23^{\mathrm{b}}$ & $35.40 \pm 1.23^{\mathrm{a}}$ & $*$ \\
$\mathrm{Hb}\left(\mathrm{g} \cdot \mathrm{dL}^{-1}\right)$ & $8.566 \pm 0.31$ & $8.784 \pm 0.31$ & $\mathrm{NS}$ \\
$\mathrm{RBC}$ per $\mathrm{mm}^{3}$ & $2040286 \pm 13$ & $2132000 \pm 13$ & $\mathrm{NS}$ \\
\hline
\end{tabular}

a, b Row means with common superscripts do not differ $(*$ : $P<0.05)$.

NS: not significant; ${ }^{1}$ Control group; ${ }^{2}$ Oxygen supplemented.

Table IV. Mean values of heart parameters of oxygen supplemented and control groups at the 5th week of age ( $\bar{X}_{ \pm}$standard error of the mean).

\begin{tabular}{lccc}
\hline Heart Parameters & $\begin{array}{c}\text { Control } \\
\mathrm{n}=10\end{array}$ & $\begin{array}{c}\text { Oxygen Supplemented } \\
\mathrm{n}=10\end{array}$ & Significance \\
\hline Body Weight (g) & $1812.25 \pm 42.20$ & $1870 \pm 42.20$ & $\mathrm{NS}$ \\
Right Ventricle (RV) Weight (g) & $2.04 \pm 0.03$ & $2.10 \pm 0.03$ & $\mathrm{NS}$ \\
Left Ventricle + Septum Weight (g) & $7.15 \pm 0.09$ & $7.21 \pm 0.09$ & $\mathrm{NS}$ \\
Total Ventricle (TV) Weight (g) & $9.19 \pm 0.12$ & $9.31 \pm 0.12$ & $\mathrm{NS}$ \\
RV:TV Ratio & $0.22 \pm 0.01$ & $0.23 \pm 0.01$ & $\mathrm{NS}$ \\
\hline
\end{tabular}

NS: not significant.

et al. [38] observed reductions in BW gain when birds were reared at lower levels of atmospheric $\mathrm{O}_{2}$. Vanhooser et al. [33] also demonstrated that low environmental $\mathrm{O}_{2}$ severely reduced weight gain and feed efficiency of broiler chicks. Liu et al. [18] concluded that BW at 8 weeks of age was correlated with embryonic $\mathrm{O}_{2}$ consumption on day 14-19 of incubation. Jones [12] reported an improvement in feed conversion ratio and an increase in $\mathrm{BW}$ of $8 \%$ when oxygen content within the hatching cabinet was maintained at $23 \%$. In the current study, the oxygen-supplemented group had a significantly higher mean final BW, feed consumption and feed conversion ratio than the control group. Such improvements in BW and feed conversion ratio with increases in oxygen concentration suggest that broilers may be environmentally limited in their genetic capacity to convert feed to gain and to grow at optimal rates [12].
The high metabolic demands of today's fast growing broiler, together with insufficient oxygen availability lead to hypoxia, which triggers ascites. Because hypoxia is believed to be the primary cause of ascites, its incidence is increased in circumstances that impose greater metabolic demands, particularly during the period of rapid juvenile growth when the metabolic rate is very high [7,37]. Beker et al. [3] demonstrated an inverse relationship between oxygen consumption and ascites incidence $\left(R^{2}=0.96\right)$. Beker et al. [4] found that final BW, BW gain, feed consumption and gain to feed ratio increased quadratically as the partial pressure of $\mathrm{O}_{2}$ rose from $12 \%$ to $20.6 \%$, while ascites heart ratio, ascites score, right ventricular mass and hematocrit increased as partial pressure of $\mathrm{O}_{2}$ decreased. Additionally, Vander Hel et al. [32] compared 1 d old chicks exposed to $15 \% \mathrm{O}_{2}$ with control birds exposed to $20.9 \% \mathrm{O}_{2}$. Ascites was observed 
in the birds exposed to low $\mathrm{O}_{2}$ at $21 \mathrm{~d}$. Furthermore, the birds exposed to low levels of $\mathrm{O}_{2}$ weighed $600 \mathrm{~g}$ less and had a packed cell volume $50 \%$ higher than the control birds at $32 \mathrm{~d}$. In the present study, oxygen supplementation during hatching did not cause significant changes in $\mathrm{RBC}, \mathrm{Hb}$ and Glucose. However, PCV increased in the oxygen supplemented group at the 5th week of age. Luger et al. [20] found that ascetic broilers exhibited similar hematocrit values in control and healthy broilers. Therefore, it is possible that the association between the ascites syndrome and hematocrit, reported by Shlosberg et al. [29] may not always be evident. It may be that none of these blood parameters can predict the development of ascites at an early age.

Mortality due to ascites of this nature was $0.37 \%$ in the oxygen-supplemented group, compared with $2.96 \%$ in the control group. It must be noted that, numerically, this was only a difference of seven birds (8-1), and thus statistically, the difference was not significant. However, this observation is still important in spite of the lack of a significant difference between treatments. In the present study, mortality results were in agreement with those of Beker et al. [3, 4], Vander Hel et al. [32].

Under a wide variety of conditions, clinically healthy domestic fowl with normal pulmonary arterial pressures have RV:TV ratios ranging from 0.15 to 0.27 , whereas sustained pulmonary hypertension causes RV:TV ratios to increase above $0.28[13,15,19]$. In this study there were no differences in RV:TV ratios between the groups at 5th weeks, and neither of the two groups exceeded this 0.27 limit. It is unclear whether or not these birds would have eventually developed full ascites.

It was concluded that oxygen supplementation from 18 to $21 \mathrm{~d}$ of incubation increased chick weight, final body weight, growth rate and feed efficiency of the broilers. The data from the present study, suggest that oxygen supplementation during incubation can be used to improve broiler performance.

\section{REFERENCES}

[1] Al-Murrani W.K., Maternal effects on embryonic and post embryonic growth in poultry, Brit. Poultry Sci. 19 (1978) 277-281.

[2] Altan O., Sahan U., Ipek A., Aydın C., Effects of oxygen supplementation on embryonic survival, haematological parameters and plasma glucose level of broiler chicks, Arch. Geflugelkd. 70 (2007) (in press).

[3] Beker A., Vanhooser S.L., Teeter R.G., Effects of oxygen level on ascites incidence and performance in broiler chicks, Avian Dis. 39 (1995) 285-291.

[4] Beker A., Vanhooser S.L., Swartzlander J.H., Teeter R.G., Graded atmospheric oxygen level effects on performance and ascites incidence in broilers, Poultry Sci. 82 (2003) 1550-1553.

[5] Christensen V.L., Wineland M.J., Yıldırım I., Ort D.T., Mann K.M., Incubator temperature and oxygen concentration at the plateau stage affect cardiac health of turkey embryos, J. Anim. Vet. Adv. 3 (2004) 52-65.

[6] Coleman M.A., Coleman G.E., Ascites control through proper hatchery management, Misset World Poultry 7 (1991) 33-35.

[7] Decuypere E., Buyse J., Buys N., Ascites in broiler chickens: exogenous and endogenous structural and functional causal factors, World Poultry Sci. J. 56 (2000) 4, 367-377.

[8] DeWill E., Buys N., Albers G.A.A., Decuypere E., Different characteristics in chick embryos of two broiler lines differing in susceptibility to ascites, Brit. Poultry Sci. 37 (1996) 1003-1013.

[9] Hernandez A., Hypoxic ascites in broilers: a review of several studies done in Colombia, Avian Dis. 31 (1987) 658-661.

[10] Hoyt D.F., A new model of avian embryonic metabolism, J. Exp. Zool. (Suppl. 1) (1987) 127-138.

[11] Huchzermeyer F.W., Deruyck A.M.C., Van Ark H., Broiler pulmonary hypertension syndrome, III. Commercial broiler strains differ in their susceptibility, Onderstepoort J. Vet. 55 (1988) 5-9.

[12] Jones G.P.D., Response of broilers susceptible to ascites when grown in high and low oxygen environments, Brit. Poultry Sci. 36 (1995) 123-133.

[13] Julian R.J., Pulmonary hypertension as a cause of right ventricular failure and ascites in broilers, Zootecnica Intern. November (1988) 58-62. 
[14] Julian R.J., McMillan I., Aquinton M., The effect of cold and dietary energy on right ventricular hypertrophy, right ventricular failure and ascites in meat type chickens, Avian Pathol. 18 (1989) 675-684.

[15] Julian R.J., Ascites in poultry, Avian Pathol. 22 (1993) 419-454.

[16] Julian R.J., Physiological, management and environmental triggers of the ascites syndrome: a review, Avian Pathol. 6 (2000) 519527.

[17] Lirette A., Towner R.A., Liu Z., Janzen E.G., Chambers J.R., Fairfull R.W., Milligan L.P., Crober D.C., Nuclear magnetic resonance spectroscopy hydrogen-1, phosphorus-31 of chicken embryos (day 0 to 20 ) from two broiler strains of varying fat content, Poultry Sci. 72 (1993) 1411-1420.

[18] Liu Z., McBride B.W., Lirette A., Chambers J.R., Characterization of embryonic oxygen consumption of two broiler chicken lines differing in body fat content, Can. J. Anim. Sci. 75 (1995) 115-119.

[19] Lubritz D.L., Smith J.L., McPherson B.N., Heritability of ascites and the rato of right to total ventricle weight in broiler breeder male lines, Poultry Sci. 74 (1995) 1237-1241.

[20] Luger D., Shinder D., Rzepakovsky V., Rusal M., Yahav S., Association between weight gain, blood parameters, and thyroid hormones and the development of ascites syndrome in broiler chickens, Poultry Sci. 80 (2001) 965-971.

[21] Maxwell M.H., Robertson G.H., Spence S., Studies on an ascitic syndrome in young broilers, 1: Hematology and pathology, Avian Pathol. 15 (1986) 511-524.

[22] Maxwell M.H., Spence S., Robertson G.W., Mitchell M.A., Heamatological and morphological responses of broiler chicks to hypoxia, Avian Pathol. 19 (1990) 23-40.

[23] Maxwell M.H., Robertson G.W., Moseley D., Serum troponin T values in two strains of commercial broilers aged one to 56 days, Res. Vet. Sci. 58 (1995) 244-247.

[24] Muramatsu T., Hiramoto K., Okumura J., Strain differences in whole-body protein turnover in the chicken embryo, Brit. Poultry Sci. 28 (1990) 165-172.

[25] SAS Institute Inc., A user's guide to SAS, SAS Institute Inc., Cary, NC, 1989.

[26] Schalm O.W., Jain N.C., Caroll E.J., Veterinary Haematology, 3rd ed., Lea and Febiger, Philadelphia, 1975, pp. 15-81.

[27] Scheele C.W., DeWit W., Frankenhuis M.T., Vereijken P.F.G., Ascites in broilers. 1. experimental factors evoking symptoms related to ascites, Poultry Sci. 70 (1991) 1069-1083.
[28] Shlosberg A., Pano G., Handji J., Berman E., Prophylactic and therapeutic treatment of ascites in broiler chickens, Brit. Poultry Sci. 33 (1992) 141-148.

[29] Shlosberg A., Bellaiche M., Berman E., Perk S., Deeb N., Neumark E., Cahaner A., Relationship between broiler chicken hematocrit-selected parents and their progeny, with regard to hematocrit, mortality from ascites and bodyweight, Res. Vet. Sci. 64 (1998) 105-109.

[30] Stock M.K., Metcalfe J., Stimulation of growth of the chick embryo by acute hyperoxia, Respiration Physiol. 58 (1984) 352358.

[31] Tullet S.G., Burton F.G., The recent reawakening of interest in birds physiology particularly eggs, eggshell porosity and embryonic respiration, Wiss. Zeitschrift der Humboldt Universitat zu Berlin, Mathematisch-Naturwissenschaftliche Reiche 35 (1986) 273-284.

[32] Vander Hel W., Henken A.M., Viser J., Frankenhuis M.T., Induction of ascites by low environmental oxygen pressure, in: Environmental and animal health proceedings of the 6th International Congress On Animal Hygiene, Skara, Sweden, 1988, p. 575.

[33] Vanhooser S.L., Beker A., Teeter R.G., Bronchodilator, oxygen level and temperature effects on ascites incidence in broiler chickens, Poultry Sci. 74 (1995) 1586-1590.

[34] Visschedijk A.H.J., The air space and embryonic respiration. 1. The pattern of gaseous exchange in the fertile egg during the closing stage of incubation, Brit. Poultry Sci. 9 (1968) 173-184.

[35] Wideman R.F. Jr., Ascites in poultry, Monsanto Nutrit. Update 6 (1988) 1-7.

[36] Wideman R.F., Tackett C., Cardiopulmonary function in broilers reared at warm or cold temperatures: effect of acute inhalation of $100 \%$ oxygen, Poultry Sci. 79 (2000) 257-264.

[37] Wideman R.F., Pathophysiology of heart/lung disorders: pulmonary hypertension syndrome in broiler chickens, World Poultry Sci. J. 57 (2001) 289-307.

[38] Witzel D.A., Huff W.E., Kubena L.F., Harvey R.B., Elissalde M.H., Ascites in growing broilers: A research model, Poultry Sci. 69 (1990) 741-745.

[39] Yersin A.G., Huff W.E., Kubena L.F., Elissalde M.H., Harvey R.B., Witzel D.A., Giror L.E., Changes in haematological, blood gas, and serum biochemical variables in broilers during exposure to simulated high altitude, Avian Dis. 36 (1992) 189-196. 